ELS Journal on Interdisciplinary Studies on Humanities

Volume 2 Issue 4, 2019

ISSN (print) : 2621-0843

ISSN (online) : 2621-0835

Homepage : http://journal.unhas.ac.id/index.php/jish

\title{
Mother Behavior to Their Daughters As Seen in "Pride and Prejudice" and "Little Women"
}

\author{
Fitri Arniati ${ }^{1}$, Muhammad Darwis ${ }^{2}$, Nurhayati Rahman ${ }^{3}$, Fathu Rahman ${ }^{4}$ \\ ${ }^{1}$ fitriarniati 168@gmail.com
}

\begin{abstract}
This research is to study about the mother behavior to their daughters as seen in "Pride and Prejudice" and "Little Women". The mother behavior to their daughters show the different way of women as a mother in bringing up their children according to their social and condition at the time. The data were taken from two novels entitled "pride and prejudice" and "little women" is the topic of the study. The women held in the early 19th century and the late 19th century was described as one that belonged in the home as a wife and mother, and that should marry a man who can support their family. Also throughout the novel women's role in society was described as one that is to be accomplished in household chore and those of entertainment, such as singing and playing music. The role of women in society was a major theme throughout the novel "Pride and Prejudice" and "Little Women" The method used in this research is a study of comparative literature to analyze mother behavior especially for Mrs. Bennet, Lady Catherine de Bourgh, These women have similarities and different behavior in find the right mate for their daughters. This study shows that every woman has characteristics in caring for their children and paying attention to the survival of their children.
\end{abstract}

Keywords: mother behavior; daughters; mate

How to cite: Arniati, F., et. al. (2019). Mother Behavior to Their Daughters As Seen in "Pride and Prejudice" and "Little Women". ELS Journal on Interdisciplinary Studies in Humanities, 2(4), 620-625

\section{Introduction}

Literature reflects the various experiences, ideas, passions of human beings in their daily life that express on several forms and styles of literary works. Since literature directly derives from human life, it can increase our knowledge and experiences about human problems including, morals, cultures and human interest. Wellek and Warren, (1956) said literature is a creativity and art without artistic values literature would be just another kind writing, along with scientific, works, report, ect. (Serli, 2017) moreover, literature and human life are difficult to separate. Literary work tells about life itself as the inspiration of the author to produce a literature. Literary works appear as the outcome of people imagination and reflect the social symptoms. Therefore, existence of literature is related to society life. Novel is one of diction works that is closely related to life or to actual people or events. So, the actions and events in the novel might be true in everyday life. This means that novel

\footnotetext{
1,2,3,4 Hasanuddin University, Indonesia 
is result of the work of an author, which is usually based on imagination of the real action.

Novel is a kind of literary works that represents some aspects taken from the real life or some experiences. It is a kind of mirror of the society which always shows the situation of the real world society at the time. Clara Reeves in (Abrams, 2001) book said, "Novel is a picture of real life and manners and of the time in which it is written". Furthermore, Tobias Smollet in Wilter Allen's book is as follows: a novel is a large diffused picture, comprehending the character of life, disposed in different groups and exhibited in various attitudes, for the purpose of propriety, or success, without a principal personage to attract the attention. Unite the incidents and unwind the clue of the labyrinth and at last close the scene by his experience (Allen, 1958).

Pride and Prejudice tells us about one family, which called the Bennets. The Bennets consist of Mr. Bennet, a country gentleman who is father of five daughters and the husband of Mrs. Bennet. Their five daughters are: Jane who is pretty, shy, calm, gentle and is said to be good-natured, Elizabeth is second daughters who is lively, intelligent, witty and sensible. Mary the third is depicted as pedantic girls beside tasteless, plain, vain, silly, and affected. addiction, the last one is Lydia, the youngest daughter who is a stout, well-grown girl of fifteen, with a fine complexion and good humored countenance. The novel is set the nineteenth century in England. More precisely around Longbourn, the Hertfodshire country town that is a mile from Meryton and twenty-four miles from London.

The novel Little Women is also about one family called The Marches. The Marches consist of parents (Mr. amd Mrs. March), Auntie Hanna, The House keeper and four daughters, their named Meg, Jo, Beth and Amy. The setting of Little Women is about nineteenth century in New England, Concord, Massachusetts in the United States. Mr March is in Washington DC involved in civil war. Therefore Mrs. March must work in order to support her life and family without her husband around her . it is not easy to Mr. March to handle her four daughters who are still immature and do not understand enough about life. Meg, Jo, Beth and Amy are kind and nice daughters. They always obey their mother's words although sometimes make some troubles. They also love one another, give exchanges mutual advices, protect but also sometimes they are quarrel and hate each other, but they can handle it well because their mother is a wonderful woman, in spite of difficult situation that Mrs. March has to face all the absence of her husband. She can overcome by all means, the problem raised, unwillingly by her daughters.

England during nineteenth century, Britain was transformed by the industrial revolution. In 1801 based on http://www.loca/histories.org. at the time of the census, only about $20 \%$ of the population lived in towns. By 1851 the figure had risen to over $50 \%$. By 1881 about two thirds of the population lived in towns. Furthermore in 1801 the majority of the population still worked in agriculture or related industries. Most goods were made by hand and very many craftsmen worked on their own perhaps a 
laborer and an apprentice. By late, the nineteenth century factories were common and most goods were made by machine.

In the nineteenth century (1801-1900), Queen Victoria led the government for quite a long time period. Abrams (2001) states that, during the reign of Queen Victoria, a woman's place were at home, as domestically and motherhood were considered by society to be sufficient emotional fulfillment for females. These constructs kept women far away from the public sphere in most ways, but during the nineteenth century, charitable missions did begin to extend the female role of service, and Victorian feminism emerged as a potent political force.

Women of the middle classes spent more time with their children than their predecessors. They were more likely to breast-feed, to play with and educate their children, and to incorporate them in the day-to day life of home. Middle class women who, by mid century, were giving birth 'confined' within the home, now achieved true womanhood if they responded emotionally to their infants and bonded with them through breast-feeding and constant of their identity.

For the addiction, Wojtcak (2000) states that women of the mid 19th century had no such choices in their life. Most of them lived live in a state little better than slavery. They had to obey, because most cases men held all the resources and women had no independent means of subsistence. Girls received less education than boys, were barred from universities, and could obtain only low-paid jobs. Women's sole purpose was to marry and reproduce.

Casselman (2011) states that English mother and Latin mater and many similar maternal words contain the worldwide etymon ma 'breats' + ter an Indo-Europian agent suffix, so that the etymological meaning of the word mother 'breat-feeder'.

Mamma is a reduplication of the much older Proto-Indo-European root *ma, mother. This is not only first sound uttered by many human infants; it may also widespread word root in the world.

The word mother brings many different thoughts and images to the mind of every individual on this planet. According to Echoes (2007), mother is a woman who will stay at home 24 hours of the day, 7 days out of week to be with her children and raise them, watch them grow, and nurture their lives every waking moment of the day. To others, the definition of mother is a woman who willing to leave the home and work to support her family, to climb through corporate ladders or simply ring up customers at a local store to bring home financial gains for her family so that she knows they are secure and taken care of in the lifestyle she believes they should have. Besides, mother is she who raises her child within a religious household, pushing and guiding them passage into a beautiful afterlife. In addition, Saxton (1968 : 369) states her roles are mainly relational and educational : she is expected to provide emotional and physical nurture, both to her children and to her husband, treat for the children in skills, roles appropriate to their socialization. 
This paper deal with comparative literature to know mother behavior to their daughters, the term comparative literature first appeared in the United Kingdom which pioneered by some French Thinkers such as Femand Baldensperger, Jean Marie Carre, Paul van Tieghem, and Marius-Francois Guyard. They were in science of comparative literature at last better known as the French pioneers or the old flow (Hutomo, 1993). Comparative literature is study of the relationships between literature on the one hand and other areas knowledge and belief, such as the arts (e.g., painting, sculpture, architecture, music) in brief, it is comparison of one literature with another or others, and comparison of literature with other spheres of human expression, this paper adopts the comparative perspective using synchronic method because these novels were published in the same period, the nineteenth century.

\section{Objectives of the study}

The purpose of writing this article is formulated as follows: I) describing and analyzing the form of Jane Austin's style of language in the Pride and Prejudice Novels, and 2) describing the author's rhetorical choice in exposing the ideology of feminism.

\section{Mother Behaviors to Their Daughters}

In this paper there are two women as a mother, there are Mrs.Bennet, Lady Catherine de Bourgh, and Mrs. March these women have similarity and different way to find the right mate for their daughters, the major role they have to carry out is to find out a rich man and well to do people for their daughters.

Mrs. Bennet comes from middle class, in the beginning of the story, we already know about Mr. Bingley is the main target of Mrs. Bennet because of his wealth. Based on the Mr. Bingley family background, Mrs. Bennet plans to marry Mr. Bingley to one of her five daughters. She wants it because she hopes her daughter could be happy even after ifthey are married with wealth men.

'What is his name?'

'Bingley

'Is he married or single?'

'Oh! Single, my dear, to be sure! A single man of large fortune; four of five thousand a year. What a fine thing for our!' (Austen, 1962: 9)

Mrs. Bennet is materialist, for the first is when Mrs. Bennet knows about Mr. Bingley which is wealth, handsome and single man coming to her village. Immediately, Mrs. Bennet orders to her husband, she wants her husband visiting Mr. Bingley when he enters for the first time in their village. Before, when Mr. Bennet with Mrs. Bennet, he talks never attending to Mr. Bingley's house. Mrs. Bennet shows again her materialist when she knew about british Jaw concerning her family property. She will not have occasion for stay long time in her house. Lonboum because of Mr. Collins, Mr. Collins is the only one 
who is taking Mr. Bennet wealth when he passed away. After that, Mrs. Bennet tries matchmaking her daughter, Lizzy to him. In line with Mrs. Bennet wish actually Mr. Coll ins has planning to marry one of his nieces. The first niece of Mr. Collins target is Jane but Mrs. Bennet rejects it because Jane already has Mr. Bingley Then, Mr. Collins moves to Lizzy. Below is the quotation about it:

'Mr. Collins had only to change from Jane to Elizabeth and it was soon done-done while Mrs. Bennet was stirring the fire." (Austen, 1962:64)

Mrs. Bennet never desperate finding single and rich men for her daughters because she has a special dream in her life. She has dream having social status, and better life without any deficiency. Until one day she is very happy because the relationship between Jane and Mr. Bingley are getting better. All the forms of pleasure and happiness will come to Mrs. Bennet if her daughter, Jane married to Mr. Bingley. Next is a dream of Mrs. Bennet happiness that describes in the quotation below:

"Mrs. Bennet was perfectly satisfied, and quitted the house under the delightful persuasion that allowing for the necessary preparations of settlements, new carriages, and wedding c1othes, she should undoubtedly see her daughter married to Mr. Collins, she thought with equal certainty, and considerable, thought not equal, pleasure. Elizabeth was the least dear to her of all her children; and though the man and the match were quite good enough for HER, the worth each was eclipsed by Mr.Bingley and Netherfield." (Austen, 1962:91)

Lady Catherine de Bourgh is aunt of Mr. Darcy, she is the younger sister of lady Anne Darcy. She is the younger sister of Lady Anne Darcy, she is also the widow of Sir Lewis de Bourgh. From her marriage, she has a daughter named Miss Lady Catherine de Bourgh, she weak since young so Lady Catherine de Bourgh gives more attention to her.

Lady Catherine de Bourgh shows her love and care to her only one daughter, Miss de Bourgh. She hopes that Mr. Darcy could become her son in law. In the beginning, Mr. Darcy did not interrupt in his aunt decision until he meets Lizzy, then Mr. Darcy falls in love with her because of his feeling, he breaks his engagement with Lady Catherine de Bourgh daughter. After knowing his reason, Lady Catherine de Bourgh makes effort to break the relation between Mr. Darcy and Lizzy because she has the plan to marry with her daughter to Mr. Darcy.

In finding the right mate for her daughters these women also has different way to show as Mrs. March advised her daughters if they like do not look someone from the property owned but behold his love.

"Hadn't you rather have her marry a rich man ?" asked Jo, as her mother's voice faltered a little over the last words.

"Money is good and useful thing, Jo, and I hope my girls will never feel the need of it too bitterly, nor be tempted by too much. I should like to know that John was firmly established in some good business, which gave him an income large enough to keep free from debt and make Meg comfortable. I'm not ambitious for a 
splendid fortune, a fashionable position, or a great name for my girls, if rank and money come with love and virtue, also, I should accept them gratefully, and enjoy your good fortune, but I know, by experience, how much genuine happiness can be had in a plain little house, where the daily bread is earned, and some privations give sweetness to the few pleasures. I am content to see Meg begin humbly, for if I am not mistaken, she will be rich in the possession of a good man's heart, and that is better than a fortune" (Alcott, 1868:240-241).

At the time, they were gathered together and then they come to the topic of Meg and Brooke. Brooke is a person confidant and he also helped Mr. March when he was ill, he was also close to Mrs. March and her four daughters. Broke likes Meg returns those feelings. One day, Mrs. March felt Meg being different, she was often pensive, dreamy, and sometimes blushes. After she knew Meg condition, she gave her advising as in the citation above.

\section{Conclusion}

From the behaviors of women above as a mother for their daughters, some point to learn for being honest in this life. In Pride and Prejudice and Little Women shows caring and loving to their daughter, they have different ways based on different goals, also think about the right person to their daughter. For Mrs. Bennet and Lady Catherine de Bourgh, they shows their love by their efforts to find suitable mate for their daughters. For the Marches and The Hummel's values loves as the most important things in this earth, the united companions and togetherness among family member should be preferable. Both novels, show the different way of women as a mother in bringing up their children according to their social and condition at the time.

\section{References}

Abrams, L. (2001). Ideals of Womanhood in Victorian Britain By Lynn Abrams Ideals of Womanhood in Victorian Britain.

http://classwithmpenton.weebly.com/uploads/1/3/6/3/13638874/janeeyreidealsof womanhoodactivity.pdf

Allen, W. (1958). Writers On Writing. Phoenix House Ltd.

Casselman, B. (2011). Etymolgy of Mother. http://www.billcasselman.com/wordingroom/mother.htm

Hutomo, S. (1993). Merambah Matahari: Sastra dalam Perbandingan. Gaya Masa.

Serli, E. (2017). Struggle Of Woman in the Novel Sing All To Sleep By Angela Morrison (The Analysis of Feminism). UIN Alauddin Makassar.

Wellek, R., \& Warren, A. (1956). The Mode of Existence of a Literary Work of Art. In Theory of Literature.

Wojtcak, H. (2000). Women's Status in mid 19th century England. English Socia History. Women of Hastings \& St. Leonards. 